\title{
Are terminology planning evaluation and language policy and planning evaluation applicable to the evaluation of standardisation?
}

\author{
Joan Costa-Carreras \\ Department of Translation and Language Sciences, Pompeu Fabra University, Barcelona, Spain
}

Post-print version of the article:

Costa-Carreras J. Are terminology planning evaluation and language policy and planning evaluation applicable to the evaluation of standardisation?. Current Issues in Language Planning. 2018;0(0):[21 p.]. DOI: 10.1080/14664208.2018.1553913.

\begin{abstract}
This initial work on evaluating standardisation tries to explore to what extent standardisation can be evaluated in the same way as terminology planning and language policy and planning. The main reason for exploring this issue is that this kind of evaluation is necessary and has not been undertaken systematically. The work aims to verify the basic hypothesis that terminology planning evaluation (TPE) and language policy and planning evaluation (LPPE) can be applied to the evaluation of standardisation. So, the general question addressed is to what extent can standardisation be evaluated according to the models for TPE and LPPE. After presenting Haugen's model of standardisation and complementing it with some concepts about language corpus planning and restandardisation, this model is analysed from the perspectives of PPE and LPPE, with references to the actions taken as part of the official restandardisation of the Catalan language (the new 2016 Catalan spelling and grammar). The principal original contributions of our work are this analysis of a standardisation model, based on TPE and LPPE evaluation models, and an overall positive verification of the hypothesis, leading us to conclude that standardisation can be evaluated in this way.
\end{abstract}

KEYWORDS

Catalan language; evaluation of codification; evaluation of language policy and planning; evaluation of standardisation; evaluation of terminology planning

\section{Acknowledgements}

We must thank Carla Amorós Negre, Wendy Ayres-Bennett, Teresa Cabré and Mireia Trenchs for their very insightful comments on the first draft of this work. Obviously, any remaining shortcomings are my sole responsibility.

Reasons for exploring the possibility of evaluating language standardisation

This work assumes that there are ethical, academic and epistemological reasons, as well as academic and contextual opportunities, for exploring the possibility of evaluating the restandardisation of Catalan, as reflected in the new official grammar and orthography introduced by the Institute of Catalan Studies (IEC, 2016; IEC, 2017).

One of the ethical reasons for this evaluation is the need to assess the current official restandardisation and monitor how it is being implemented (as requested by Amorós, 2008, p. 40), since Catalan speakers feel extremely insecure (Haugen \& Dill, 1972, pp. 148-158) about the linguistic norm and they have time until January 2021 to implement these new norms. Besides, following Gazzola (2014, p. 338), it is necessary 'to clarify and assess the effects of language policies on the well-being of people'.

Among the academic or epistemological reasons, the first oneis the fact that standardisation is at an intermediate level epistemologically, between terminology planning (TP; Fathi, 2017, p. 22, 27) and language policy and planning (LPP). Based on Haugen's (1983) model, restandardisation is equivalent to a recodification and reimplementation, so it consists of two actions at the same level as elaboration, within which there is terminology planning (see the section 'Verification of the hypothesis'). The second reason is that there is a parallelism between codification and elaboration (thus, also in TP): in both fields there is a prescription, which is disseminated and has to be used by the target population. Hence, it makes sense to 
explore to what extent one of the analytical frameworks that has been established for terminology can be transferred to standardisation.

Among the academic and contextual opportunities, the first one is our own (Costa, 2016b; CostaCarreras, in press) development for standardisation in general of Vila and Nogué's (2007, p. 35) 'frame of favourable sociolinguistic conditions' (FFSC) for terminology implantation. The second opportunity in this area is our knowledge of the documents of the Catalan Institute of Public Policy Evaluation (Ivàlua), as well as the works of Amorós (2008), Gazzola (2014) and Fathi (2017). And the third opportunity is the fact that the current President of the official Catalan body for language codification (the Philological Department of the Institute for Catalan Studies, IEC), Teresa Cabré, is a specialist in TPE and was responsible for supervising Fathi's thesis (2017). Last but not least, we must take into account the presence of the Superior Council for Assessing the Education System (CSASE) in Catalonia.

\section{Epistemology of this work}

The aim of this paper is to analyse how Fathi's (2017) and Gazzola's (2014) frameworks and techniques apply to the evaluation of language standardisation (Cooper, 1989; Haarman, 1990; Haugen, 1983; Kaplan \& Baldauf, 1997; and Spolsky, 2004). The expected output of this work is a seminal presentation explaining to what extent language standardisation is evaluable in the same way as both TP (specifically) and LPP (generally). This kind of research has never been undertaken before (according to Amorós, 2008, pp. 89-93).

The hypothesis to be confirmed in this work is that Catalan restandardisation can be evaluated in the same way as TP, since standardisation is epistemologically and professionally at an intermediate level between TP (Fathi, 2017, p. 22, 27) and LPP. As a result, theory and practice on the evaluation of standardisation can benefit, academically and professionally, from theory and practice for TPE and LPPE.

This work is based on some assumptions about LPPE, TPE, language standardisation evaluation (LSE) in general and the evaluation of Catalan restandardisation. As for the assumptions about LPPE, the first one is that policy evaluation theory has been developed extensively and extremely well in LPP, as illustrated in Gazzola's (2014) work. In terms of practice, there is still a lot of work to be done. With respect to the assumptions about TPE, it must be said that TPE theory has been developed widely and adequately, as can be seen in Fathi (2017), although there is still a lot of work to be done to put the theory into practice.

Among the assumptions about language standardisation evaluation in general, the contribution of Amorós (2008, pp. 89-93) must be highlighted, especially in relation to designing alternative policy intervention plans (Amorós, 2008, p. 12). There is also the premise that language standardisation is usually a 'public policy', as are TP (Fathi, 2017) and LPP (Gazzola 2014) and, therefore, must be evaluated (Amorós, 2008, pp. 89-93; Gazzola 2014, p. 2; Fathi, 2017).

Regarding assumptions about Catalan restandardisation evaluation, as already mentioned, the first assumption is the need to assess to what extent Catalan is standardised, in the broadest sense. Secondly, we can adapt Ricento's (2016, p. 2) statements about English to the codification of Catalan: the acquisition and use of codified Catalan can provide economic and social advantages for individuals, depending on a host of co-occurring factors and on the context of its acquisition and use. Thirdly, as it is alluded to in the previous excerpt by Ricento(2016,p. 2), Gazzola's 'fairness' must be taken into account. Fourthly, regarding output evaluation, we assume that there is a duty to assess official Catalan output. In fifth place, following Gazzola's 'intermediate' evaluation and Gazzola's and Fathi's effectiveness and efficiency evaluation, we assume that implementation must be monitored. In sixth place, regarding Fathi's 'systematic' level evaluation of restandardisation, we assume (a) that the IEC has the duty to monitor language normalisation (IEC, 2015, p. 9); (b) that it must deal with language variation with 'relevance', 'effectiveness', 'fairness' and 'efficiency' (Gazzola 2014; p. 54 and Fathi, 2017) and evaluate the impact of its intervention; and (c) that 
some administrations in the Catalan linguistic domain have been applying normalisation plans which have included corpus planning measures. And, last but not least, it must be kept in mind that there are different degrees of restandardisation (Amorós, 2014, p. 147) in this domain: on the one hand, new norms have been selected for codification, which has been completed and updated; but, on the other hand, this codification, has not been implemented neither in the same way nor with the same systematicity in all the Catalanterritories.

In relation to the assumptions about Fathi's and Gazzola's 'context/involving factors' of restandardisation, the Catalan language is assumed to have internal variation, and speech communities within the Catalan speaking domain are assumed to be multilingual and show different attitudes towards language (Haarman's, 1990 'prestige planning').

And finally, at the level of Fathi's 'intrasystemic factors' of standardisation, paraphrasing her statements, we assumed that the IEC's recodification must satisfy its users' needs.

Turning to the theoretical basis of this work, it is mainly underpinned by the courses given by Ivàlua, and the works of Amorós (2008), Gazzola (2014) and Fathi (2017). The reason for choosing these two frameworks is that they are both updated complete and coherent models to evaluate, the first terminology implantation, the second language policy and planning, which allow to apply them to the evaluation of standardisation.

With respect to methodology, after presenting Haugen's (1983) model of standardisation, complemented by the concepts of Cooper (1989) and Cerruti, Crocco, and Marzo (2017), ${ }^{1}$ this model will be analysed from the perspectives of Fathi (2017) and Gazzola (2014), and a summary will be made of what has been written in the official Catalan standardisation documents (Costa, accepted), so that the hypothesis of the work can be verified.

Verification of the hypothesis

The concepts of restandardisation and standard language

In examining the concept of 'restandardisation' we must first define the original concept of 'standardisation'. The most accepted standardisation model is the one established by Haugen (1983, p. 275). Following this model, a standardised language is one within which a variety has been selected, codified, implemented and elaborated. Some comments on this model are required.

As is evident, 're-standardising' means 'standardising again'. The only observation to be made about this concept is that in this case the authors of this continuous (Joseph, 1987,

p. 89) process are the official bodies who make their prescriptions explicit. This must be clarified as Cerruti, Crocco, and Marzo (2017) analyse this process as an unmonitored social process happening outside the official bodies. ${ }^{2}$

\section{The categories status planning, corpus planning and acquisition planning}

In addition to the fields of status planning ('selection of a norm' and 'implementation') and corpus planning ('codification' and 'elaboration'), we will adopt the category 'acquisition planning' (also labelled Language-in-education planning by Kaplan \& Baldauf, 1997 or Language Education Policies by Shohamy, 2006), as proposed and justified by Cooper (1989, p. 33), which is also Fathi's (2017, p. 45) decision.

\section{'Selection (decision procedures)'}

Haugen (1983, p. 270) talks about selection as follows:

Selection or choice is only necessary when someone has identified what Neupstupny has quite rightly called a language problem. Most problems can be identified as the presence of conflicting norms, whose relative 
status needs to be assigned. This has been called an allocation of norms. The selection may be preceded by lengthy wrangling in public or private, and it may be arrived at by some kind of majority decision.

And he adds that 'language planning is a response to a social problem strongly felt by a social group' (Haugen, 1983, p. 287). So, when a language problem is identified there must be a discussion and then a decision. $^{3}$

Fathi (2017, p. 36) reproduces Haugen's scheme, mainly to talk about the place TP has within it, without commenting on anything about the 'identification of a problem'. After this, the only mention of this issue she makes is, following Corbeil (2007, pp. 98-101), the one of 'problem identification and decision-making' as the second step in terminological research (Fathi, 2017, p. 63; and some generic mentions in Fathi, 2017, p. 49, 104 and 219-220). But this does not mean that she does not propose what Gazzola (2014, p. 33) calls an 'ex ante evaluation'. She sets up, in line with Corbeil (2007, pp. 98-101), the need for 'objectives based on the users' needs and specialisation level' as the fourth step in the 'preparatory phase in terminology work'.

So the identification of a problem is not the starting point, maybe because in this sub-level of standardisation (TP) the 'problem' is always the same: the lack of terminology. But what is not the same, neither in every case nor everywhere, are the 'users' needs'. In this sense, Gazzola (2014, p. 92) makes 'the public problem to tackle' equivalent to 'the needs to be satisfied', so the conclusion has to be that the users' needs are the problem to be solved in TP. This category (the users' needs) can be considered central to Fathi's model based on the assumptions she makes (Fathi, 2017, p. 8, 35, 49, 63):

(1) User's needs are a central element of TPE as they are fundamental for evaluating its relevance, outcomes and impact.

(2) The 'profile of the users' may influence decision-making in terminology standardisation.

(3) Favourable users' expectations and attitudinal behaviour and ideology to policy-planning are essential for TP's success: terms must be known, appreciated, accepted, learned and used by them.

In her work, however, the general category of 'users' is divided into several sub-categories (Fathi, 2017 , p. $8,22,63,68-71,82,94,226)$. Some comments about them are:

(1) The 'final user' category is the opposite of the categories of 'field specialist, professional or expert', other 'participants in evaluation', terminologists and linguists.

(2) If we classify these categories according to their metalinguistic capacity (Costa, 2013, p. 277), terminologists and linguists are 'language theorists' (performing frequently as 'agents'), and the other categories fall into the "lay speakers' ${ }^{4}$ set (however, field specialists, professionals and experts have a certain degree of metalinguistic concern and capacity as they constantly need to name concepts or products).

(3) Thus, different 'needs' should be identified as there are different speaker groups involved in TP: terminologists and linguists, agents and lay speakers.

We can now move on to LPPE, as Gazzola (2014, p. 92) makes 'the public problem to tackle' equivalent to 'the needs to be satisfied'. Gazzola's work is one of the most important pieces of research in this field. A summary of the issues in Gazzola's (Gazzola 2014, p. 4, 30, 52-54, 86, 89-93, 117) work that must be discussed in relation to Haugen's model is as follows:

(1) 'Problem analysis' must be the first step to establishing a systematic and 'holistic' evaluation process in the policy cycle, which is the case in Haugen's model as it is explicit in the selection phase but is also implicit in codification in which language change and variation are evaluated in order to choose the 'best' variant to be disseminated. 
(2) A language problem is viewed as an "undesired outcome of the linguistic behaviour of a group of speakers'.

(3) The definition of the language problem must be as accurate as possible, because (1) the relevance of a policy is the consistency between the policy intervention plans and the problem to be solved, (2) a language problem is the source of a set of general objectives and a definition of the target population, (3) outcomes 'are the final effects of the policy on the public problem in question', (4) the language problem is one of the four elements of a programme theory, and (5) the public problem to solve is the standard for evaluating whether the objectives are clear and relevant. So the question is: within codification and elaboration, how should these five reasons be taken into account?

Relevance, effectiveness, ${ }^{5}$ fairness and impact are the main criteria for analysing the language problem and the actions linked to it, but there is no a priori limit to the types of criteria that can be adopted for policy evaluation, since their very nature and the importance attributed to them are a political matter.

(4) The ex ante evaluation stage starts with an assessment of the relevance.

(5) As 'the result of problem analysis is a set of general objectives and a definition of the target population', 'a solution analysis' can be discussed and formulated.

(6) The target population (or direct beneficiaries) and the 'stakeholders' (see below) must be defined as accurately as possible, because (1) the definition of the target population is the consequence of language problem analysis, and (2) outcomes are defined as the effects of the policy on the state of the target population.

The identification of the problems and users' needs in Catalan restandardisation ${ }^{6}$

As we have seen, according to Gazzola (2014, p. 92), 'the public problem to tackle' is equivalent to 'the needs to be satisfied', so it can be assumed that the public problem restandardisation should resolve is satisfying the needs of restandardisation users. Thus, the questions we will discuss in this section are (i) what is the public problem Catalan restandardisation should address and (ii) what is its target population? To do so, we will focus on the texts produced by the IEC concerning its restandardisation process, and analyse them using Fathi's and Gazzola's models.

Regarding to what extent these sources follow Fathi's and Gazzola's requirement for defining and tackling a problem, it should first borne in mind that Fathi (2017) focuses on users' needs and does not develop the concept of language problem itself. As for the issues Gazzola puts forward in relation to the IEC's texts, a summary is as follows:

(1) There is no systematic and 'holistic' evaluation process in a 'policy cycle'.

(2) The language problem is not viewed as an 'undesired outcome of the linguistic behaviour of a group of speakers'.

(3) The definition of the language problem (users' needs) about an official prescriptive corpus is established in two objective needs (see below).

(4) The only criterion which is mentioned is 'efficiency', but not as 'resource allocation' (Gazzola 2014, p. 324). The IEC papers (PEO1: 10, PEO2 8 and 10; Martí, 2006; IEC, 2016XXII, IEC, 2017, p. 18; Cabré, 2017, p. 9) refer to the capacity of the codification to allow interterritorial and stylistically unlimited communication.

(5) There is no explicit ex ante evaluation stage.

(6) No set of general objectives or solution analysis have been formulated as a result of the problem analysis. (See below for a definition of the target population).

(7) There was not only 'wide public debate' (Gazzola 2014, p. 32) but also institutional debate within the IEC (see below).

With respect to the second question, regarding what the target population of Catalan 
restandardisation is, it should firstly be remembered that both Fathi (2017) and Gazzola (2014) identified a certain diversity of people involved in the evaluation process, and this same diversity is found in the IEC papers. And regarding Fathi (2017), we have already seen that she does not develop the concept of language problem, instead she deals directly with users' needs.

The most pertinent of Fathi's assumptions to be kept in mind are the following:

(1) Users' needs are a central element of TPE as they are fundamental for evaluating its relevance, outcomes and impact. ${ }^{7}$

(2) The 'profile of the users' may influence decision-making in terminology standardisation.

(3) Favourable user expectations, attitudinal behaviour and ideology to policy-planning are essential for its success: terms must be known, appreciated, accepted, learned and used by them.

(4) Different 'needs' should be identified as there are different speakers involved in TP: terminologists and linguists, agents and lay speakers.

As for Gazzola (2014), he uses more than one term to refer to people targeted by language policy and planning: 'target population', 'direct beneficiaries', 'people with standing' and 'stakeholders' (Gazzola 2014, p. 52, 56, 72, 82, 88-89, 91). What is deduced from these categories is that a public policy must have a very well-defined target group, people with standing, or direct or final beneficiaries, who should be treated, as far as possible, as 'stakeholders' in this policy. This is necessary because (1) the definition of the target population is the consequence of a language problem analysis, and (2) outcomes are defined as the effects of the policy on the state of the target population at the end of its exposure to the policy or as soon as a programme has been completed. Hence, it is fundamental to identify all the people involved and engaged in a planning.

Regarding what the IEC papers have to say about these issues, according to them, status-planning problems existed, such as a threat against the Catalan speakers' awareness of unity and a need for a tool to meet their communicative needs. This tool had to be updated and unified in a single corpus.

Thus, the question is, given the importance of the categories users and needs, is the definition of these terms found in the IEC papers accurate enough? It is outside the scope of this work to present a detailed discussion on how the accuracy of a definition can be measured. Hence, as in the case of needs, what can be done is to compare the degree of accuracy of each definition to the other, in terms of to what extent they can be the source of a set of general objectives and a definition of the target population. Doing so, at least the work to be done on this issue will be less unclear. In this sense, the need for an updated and unified official prescriptive corpus, as it can be easily the source of a set of general objectives and a definition of the target population, is more accurate than the need of satisfying speakers' communicative needs, which, in turn, is more accurate than the need of responding to the threat against the integrity of the Catalan language. The last two needs, as they are very vague, could hardly be sources for specific objectives and target population as direct as the first one.

The user of the IEC's (2016) works is defined as an 'educated reader, not necessarily a specialised one' (IEC, 2016: XXXI). This is not the most accurate way to refer to its 'people with standing' or 'direct beneficiaries'. ${ }^{8}$ Trying to go further in this sense, we propose the following definition of 'grammar user':

Our proposal is to take advantage of the GIEC's [IEC's new grammar] stylistic conception, perhaps paradoxically, to define the target group of the norms. Since the grammar 'focuses mainly on the uses of formal styles' (IEC, 2016: XXIV), the recipient should be the one who needs Catalan in a regular way in these fields. Therefore, the target users are all persons who, in accordance with the GIEC (IEC, 2016: XXIV), need to use Catalan in interactions

-between social roles involved in secondary social relationships,

-on objective topics,

-in a public domain and

-that are not spontaneous. 
This formulation has the virtue of not linking the use of the norms to any social group a priori, but it does link them to specific communicative needs. The right combination of a basic diasystematicity in codification with the selection of prestigious forms in the formal fields ensures the best approach to the communicative needs of speakers in formal registers. (Costa-Carreras, 2018, p. 162)

\section{Relationship between 'codification' and 'elaboration',}

It must be taken into account that, although codification aims to reduce non-functional variation in formal styles and elaboration seeks to set up all the styles needed by any speakers, in fact the processes they both carry out in their sub-levels are the same: prescription and dissemination of a feature which is expected to be known, learned, valued positively and used by the target beneficiaries.

\section{'Evaluation' is linked exclusivelyto 'implementation' as 'educationalspread'. How does Haugen relate this activity toimplantation?}

Haugen (1983, p. 274) admits that 'the need for evaluation procedures pointed out by Rubin (1971) is also clear. [They are] part of any good programme of implementation, which should lead to successful listening and reading [...] speaking and writing'. So he is thinking only of an 'ex post impact evaluation of outcomes' (Gazzola 2014, p. 33), not relating either to (a) the 'selection' phase with an 'ex ante problem analysis' (Gazzola 2014, p. 55) or to (b) the 'codification' phase with an 'intermediate evaluation of outputs and activities' (Gazzola 2014, p. 55) or to (c) the elaboration phase with an 'ex ante problem analysis', with an 'intermediate evaluation of outputs and activities', or to (d) an 'ex post impact evaluation of outcomes'.

However, although Haugen (1983, p. 270) does not use the word evaluation when dealing with the 'identification of a problem', he assumes that 'the selection may be preceded by lengthy wrangling in public or private, and it may be arrived by some kind of majority decision', which, as it is unavoidable, entails some kind of evaluation.

\section{To what extent would Fathi's (2017) proposal for a TPE be applicable to standardisation evaluation?}

Given that the scope of this paper is limited ${ }^{10}$ we will make some observations and ask some questions about Fathi's (2017, pp. 221-222) 'general conclusions' on her 'analytical model', which we expect could be understood as a first step towards a standardisation evaluation and as proposals for future research.

\section{Interdisciplinarity in standardisation evaluation}

As standardisation is a theoretical and applied discipline within applied linguistics, it is interdisciplinary, as is Fathi's (2017, p. 221) model, which includes 'theoretical concepts from sociolinguistics, socioterminology, social development, planning theories and performance management'. Regarding the disciplines with a bearing on standardisation, we translate and summarise Costa's (2016, pp. 149-150) proposal:

(a) Three disciplines stand out as potentially relevant areas for the four phases of standardisation (codification, dissemination, learning and use), especially corpus planning as the discipline and activity that is committed to standardisation. As for the other two disciplines, both occupy backward, peripheral positions: in the case of prospective sociolinguistics, it may be so because it is a general perspective applicable transversally; with regard to political science, it may be due to the fact that the implementation of the norm is one of the several specific cases of language policy, which, in turn, is a specific case of politics.

(b) If we examine the areas that are present in three of the phases, we are faced with two situations. On the one hand, we find status planning, which must be said to be present because without a legal 
framework and a suitable linguistic dynamisation there can be no codification or diffusion and it can be difficult to use the norms. On the other hand, there are five areas which are all related to dissemination, learning and use: the one that seems less peripheral is linguistic anthropology, especially in contrast with the scope of the interventions on ideologies, with which it has certain thematic and methodological coincidences. It does not seem risky to speak of the interventions on skills, which have thematic coincidences with educational sociolinguistics and although they are only present in the learning phase they are in a fundamental position. The influence of the few phenomena of linguistic transmission and variationist sociolinguistics that have a relationship with these three phases that can be described as distant.

(c) An analysis of the areas which can be related to two phases reveals two situations. In the first place, demolinguistics have been attributed as a remote conditioner of codification and as a fundamental factor in the usage phase. Secondly, mention should be made of the three hypothetical areas that are relevant in the learning and usage phases: on the one hand, linguistic ecology and social psychology (the latter has a fundamental influence) and, on the other hand, the economy of the language, just as a frame.

(d) Finally, some areas are potentially relevant in only one phase and here is where we find two diametrically opposed situations: while educational sociolinguistics is the area which has by far the highest number of potentially relevant factors for the learning phase, pragmatics and discourse analysis can only have an impact on the use of norms in very specific communicative situations.

Elements of a holistic evaluation

Fathi (2017, p. 221) concludes that:

the main elements associated with a holistic evaluation in TP have been identified as objectives of the evaluation, the criteria, their associated key questions, the credible and defensible source and methods, the standards and the evidence ${ }^{11}$ to support the final report and evaluation.

Two issues arise from these conclusions: if TP is a sub-system ${ }^{12}$ of language corpus planning (LCP), then it seems reasonable to also talk of orthoepy (E), orthomorphology (M), orthosyntax (S),

ortholexicography (L) and orthography (O) as planning sub-systems of LCP. What must be analysed is whether these seven 'main elements' are the same for 'a holistic evaluation' in the five sub-systems of codification.

Objectives of the evaluation

Generally speaking, the main purposes of evaluation in corpus planning are

(a) To contribute to

(1) The improvement of interventions and quality of standardisation works or policies

(2) The effectiveness of decision-making

(3) The effectiveness of standardisation implementation

(b) To assist in accountability by reporting on the standardisation achievements. (following Fathi, 2017, p. 222)

Contribution (a1) is also proposed by Ivàlua (Ivàlua Guia pràctica 8) and Gazzola (2014), and contributions (a2-3) are also proposed by Gazzola (2014). Contribution (b) is proposed exclusively by Fathi. However, Gazzola (2014, p. 85) proposes the following objectives:

(a) 'Evaluation of the results of a policy in the light of criteria such as efficiency[:] the expected outcomes must be put in relation to [...] the resources available (efficiency criterion)'.

(b) 'Evaluation of the results of a policy in the light of criteria such as [...] fairness'. 
All these objectives could be relevant for the evaluation of orthoepy, orthomorphology, orthosyntax, ortholexicography and orthography as LCP planning sub-systems.

\section{Criteria of the evaluation}

Fathi (2017, pp. 219-220) provides a generalisation of the TP activities based on evaluation criteria (i.e. relevance, efficiency, effectiveness, and impact) in the Iranian context. Gazzola (2014, p. 90) warns that 'there is no a priori limit to the types of criteria that can be adopted for policy evaluation, since their very nature and the importance attributed to them is a political matter'.

\section{Relevance}

According to Fathi (2017), the relevance in TP can be interpreted in two ways:

(a) -The relevance of terminological activities (i.e. operations and institutional activities) to language policies [which should be, previously, in accordance with theideology and cultural images of speakers];

(b) - The relevance of terminology policies to socioprofessional and terminological needs and desires. (Fathi, 2017, p. 49)

However, Fathi (2017, p. 60) warns that sometimes this relevance cannot be feasible, and 'once conflicts arise (for a variety of reasons), three factors can be identified: persistence, resistance or change (Bastardas-Boada, 1995).'

Fathi (2017) herself makes this criterion pertinent for evaluating 'language policies'. However, it must be borne in mind that, for orthoepy, orthomorphology, orthosyntax, ortholexicography and orthography plans, the target sets are really, in principle, all community members, while terminological plans focus on field specialists. This difference makes the evaluation more difficult in the former plans than in the latter.

\section{Efficiency}

Adapting Fathi (2017, p. 112), efficiency is the relationship between the input (criteria, guidelines) and the output (standardised forms and structures) in functional and organisational procedures; that is, workflow. When evaluating organisational performance, funds, expertise, time, training programmes, etc., can be assessed and observed to see how they are converted into outputs. This can, therefore, be applied in the case of codification plans.

\section{Effectiveness}

Adapting Fathi (2017, p. 112), effectiveness is the relation between the objectives of standardisation (explicit or implicit) and the achieved outcomes (standardisation criteria, dissemination, and implantation function). It may include the availability of appropriate criteria to create and implant spellings and neologisms [and implant forms and structures] and retrospective studies for evaluating the standardisation results. So, this can be applied in the case of codification plans.

\section{Impact}

In accordance with Fathi (2017, p. 113), impact is the phonetic, morphological, syntactic, lexical and orthographic changes produced by standardisation activities, ${ }^{13}$ or any sociocultural and sociolinguistic impact resulting from standardisation interventions. It includes the consequences of dissemination (awareness), implantation (application) and standardisation functions; for example, the satisfaction of target users. ${ }^{14}$ Regarding the 'sustainability' of standardisation, it is language modernisation, and any aspect that results in continuous and stable standardisation activities. 


\section{'Equity/fairness'}

One criterion not taken into account by Fathi (2017) is equity or fairness. Gazzola (2014), on the other hand, states that:

In welfare economics the terms equity, fairness and distributive justice are generally used as equivalent [...] Together with efficiency, the analysis of the distributive effects of alternative economic states is a crucial element in debates on economic policies. [...] Distributive justice is often viewed by economists as a predominantly philosophical domain of research. (Gazzola 2014, p. 90).

It may refer either to the distributive consequences of a policy - this is the choice made in this book - or in other cases to the compliance with a given socially accepted principle of justice. (Gazzola 2014, p. 90)

Our claim is that what the Catalan academy calls 'compositionality' and 'polymorphism' have to do with equity or fairness: they respect the right that Catalan speakers have to be recognised in the official codification works and they allow to benefit all the users to the same extent, as they have a prescriptive version of the prestigious features of their dialects. A codification is 'compositional' when it takes into account all geographical varieties, the consequence of this being that it is 'polymorphic' because more than one variant is accepted for some variables. The goal of that procedure is to make all speakers feel that they are represented in this codification. The 'distributive consequences' of a compositional and polymorphic codification are that all speakers must make more or less the same effort to learn it.

Key questions associated with evaluation criteria ${ }^{15}$

'Relevance' in standardisation

Adapting Fathi (2017, p. 115), the 'relevance' questions are as follows:

(1) At the language corpus planning (LCP) and language acquisition planning (LAP) level:

(a) To what extent do standardisation activities correspond with the needs and practical requirements of the sociopolitical contexts in which they apply?

(b) To what extent do the objectives of standardisation correspond with the objectives of language policies?

(c) To what extent do standardisation activities correspond with the needs and practical requirements of the domains and target users?

(d) Were interventions in some domains more successful and appropriate than in other domains?

(2) At the theoretical level: to what extent does the basic approach towards standardisation correspond with the most recent studies in standardisation?

The only observation to be made is about question (1c): as commented in the section 'Relevance', the target users of codification have not been identified as precisely as would be required for evaluation.

\section{'Efficiency' questions}

In the line with Fathi (2017, p. 115), the 'efficiency' questions for LCP and LAP are as follows:

Are the resources and inputs efficiently used to achieve results?

(a) Criteria used in the selection of LCP and LAP input

(b) Criteria and guidelines used in the process of LCP and LAP

(c) Use of progress and achievements monitoring

(d) Coordination of the activities of the technical commissions

(e) Appropriateness of institutional resources to the LCP and LAP needs of the commissions 
'Effectiveness' questions

In accordance with Fathi (2017, p. 115), the 'effectiveness' questions for LCP and LAP are as follows:

(a) The effectiveness of LCP and LAP

(1) To what extent are the originally defined objectives realistic?

(2) To what extent are the objectives achieved?

(3) What factors are crucial for achieving or failing to achieve the objectives so far (indication of strengths and weaknesses, e.g. the monitoring and evaluation system)?

(4) What are the contributions of interventions of an authoritative body for achieving the objectives?

(5) Has the authoritative body contributed to the improvement of the resources?

(b) The effectiveness of LAP

In addition to these previous questions, these are some additional questions regarding LAP exclusively:

(1) What are the contributions of interventions of an authoritative body for achieving the objectives of standardisation dissemination?

(2) What are the contributions of interventions of an authoritative body for achieving the objectives of standardisation implantation?

(3) Has the authoritative body contributed to the improvement of standardisation awareness?

Costa (2016) provides an answer for questions (a3) and (b3).

'Impact' questions

Adapting Fathi (2017, p. 116), the 'impact' questions for LCP and LAP are as follows:

(1) What happens as a result of the plan?

(2) Does the organisational intervention contribute to the achievement of LCP and LAP development?

(3) To what extent does the intervention create structure and/or does it have a broad effect/impact regarding modelling, criteria or success indicators (e.g. adaptation among other centres and organisations)?

(4) What would the development be like without the authoritative body's interventions?

'Sustainability' questions

In accordance with Fathi (2017, p. 116), the 'sustainability' questions for LCP and LAP are as follows:

(1) Are the positive effects sustainable?

(2) To what extent will activities, results, and effects be expected to continue?

(3) To what extent does the intervention reflect on social and cultural aspects?

(4) How stable is the situation in the surrounding field of the intervention regarding social justice, economic efficiency, and political stability?

(5) What risks and potentials are visible regarding the sustainable effectiveness of LCP and LAP and how likely is it that they will occur?

(6) Is the effectiveness of the interventions most likely to improve or worsen in the future?

(7) To what extent did the system improve the overall situation of standardisation and elaboration? 
Costa (2019) puts forward the shortcomings of the IEC's viewpoint about social variation.

'Equity/fairness' (Gazzola 2014, p. 44) questions

The questions regarding 'equity/fairness' (see the section 'Equity/fairness') in codification are as follows:

(1) Does standardisation act with equity, fairness or distributive justice?

(2) Are the distributive consequences of standardisation equal, fair or distributively just for all social groups?

(3) Does standardisation comply with any socially-accepted principle of justice?

(4) Could 'compositionality' be one of these principles?

(5) Could 'polymorphism' be one of these principles?

(6) How many of the codification criteria by Lamuela (1995), Costa (2009) and Labèrnia (2015) are related to equity, fairness or distributive justice?

(7) Could 'representativeness' of any speakers be one of these principles?

(8) Is standardisation equally accessible for all social groups?

(9) Is the use of prestige as a codification criterion egalitarian, fair or distributively just for all social groups?

(10) Is the use of historicity as a codification criterion egalitarian, fair or distributively just for all social groups?

(11) Does the standard fulfila 'unifying function' (Garvin, 1992) in an egalitarian, fair or distributively just way for all social groups?

(12) Does the standard fulfil a 'participatory function' (Garvin, 1992) in an egalitarian, fair or distributively just way for all social groups?

(13) Does the standard fulfila 'reference-frame function' (Garvin, 1992) in an egalitarian, fair or distributively just way for all social groups?

(14) Does the standard fulfil a 'prestige function' (Garvin, 1992) in an egalitarian, fair or distributively just way for all social groups?

(15) Does the standard fulfila 'discriminatory function' (Lamuela, 1994) in an egalitarian, fair or distributively just way for all social groups?

Contributions of the main purposes of evaluation

A third research question in standardisation evaluation should be whether the 'main purposes of evaluation' (Fathi, 2017, p. 222) in orthoepy (EP), orthomorphology (MP), orthosyntax (SP), ortholexicography (LP) and orthography planning (OP) contribute (1) to the improvement of interventions and quality of works or policies in $\mathrm{E}, \mathrm{M}, \mathrm{S}, \mathrm{L}$ and $\mathrm{O},(2)$ to the effectiveness of decisionmaking and the implementation of these five kinds of planning, and (3) to assist in accountability by reporting on the achievements made within these five codification sub-levels.

\section{Management of the implantation evaluation}

The fourth question relates to the 'implantation evaluation' (Fathi, 2017, p. 222): would it be associated with other EP, MP, SP, LP and OP elements by manifesting the impact of E, M, S, L and O activities? Should EP, MP, SP, LP and OP 'systems' be required to manage implantation results systematically and support internal and external research attempts to obtain extensive knowledge about various subject fields?

Does Fathi (2017) define what she means by implantation?

Summarising all these excerpts, implantation according to Fathi (2017), 
(a) Is one of the types of 'impact' of the plans.

(b) Consists of having corpus planning accepted (i.e. of having it liked, learned and used).

(c) Consists of the application of standardised terms in specialised contexts.

(d) Is an achieved outcome of terminology planning.

Characteristics (a-b) and (d) are applicable to codification; characteristic (c) should be reformulated to adapt it for codification. In regards to Catalan, Costa (2016b, p. 126) states:

\begin{abstract}
In two previous works (Costa, 2013 i 2016[a]), we adapted the definition of Vila and Nogué (2007, p. 39) for the terminology implantation process to the overall process of Catalan codification, as follows: 'In codification, implantation means that target users learn, like and use the prescribed official forms, after being exposed to them in a frame of favourable sociolinguistic conditions [FFSC].'
\end{abstract}

This formulation is the characteristic (b) which Fathi (2017) cites from Fishman. As for characteristic (c), it must be said that the GIEC (2016: XXVI) sets up the degree of formality as a basic criterion of codification, distributing (if necessary) the variants of some variables into 'formal registers' and 'informal registers'. Thus, it is not unreasonable to reformulate this characteristic as follows: 'implantation consists of the application of codified forms and structures in formal contexts'.

\title{
Would the 'implantation evaluation' be associated with other $E P, M P, S P, L P$ and $O P$ elements by manifesting the impact of $E, M, S, L$ and $O$ activities?
}

As could be expected, Fathi (2017) refers to these 'associations' in TP in many excerpts (Fathi, 2017, pp. 13-14, 84, 95, 100, 221-222), the most relevant of them being the one in which 'a clear prototypical framework' is asked for, whose 'objective [...] is to define the relationship among distinct levels and to articulate the elements that could affect the [standardisation] success. [...] developing an evaluation design 'involves following key elements and how each will contribute to valid and useful evaluation results:

1. The purpose of the evaluation

2. The focus of the evaluation, that is, the key questions that the evaluation seeks to answer.

3. The sources and methods for obtaining information that is credible and defensible.

4. The procedures that will be used to analyse and interpret data and report results.

5. The standards that must be reached for the initiative to be considered successful.

6. The evidence that will be used to indicate how the initiative has performed and demonstrate its results (outputs and outcomes) Fathi (2017, p. 108).

The comments to be borne in mind when adapting the associations to codification in general are, first, that if TP is a sub-system of LCP, then it is reasonable to talk of orthoepy, orthomorphology, orthosyntax, ortholexicography and orthography as planning subsystems of LCP.

The second observation is that Fathi (2017, p. 108) states that 'according to the Handbook on Planning, Monitoring and Evaluating for Development Results, developing an evaluation design "involves the $[\ldots]$ key elements and how each will contribute to valid and useful evaluation results". In this sense the evaluation of the Catalan variable 'introducció de l'infinitiu complement o adjunt' (IICA; 'introduction of the complement or adjunct infinitive) carried out by Costa-Carreras (2018) can be described based on these 'key elements':

(1) The purpose was to analyse the degree to which this variable has been adequately codified.

(2) The focus was the extent to which codification meets the conditions of the FFSC (cf. the section 
'Does Fathi (2017) define what she means by implantation?').

(3) The sources and methods were Costa's (2016b) FFSC applied to this codification.

(4) The procedure used for analysis was the checking of each codification criterion with the data, but without any kind of interpretation.

(5) The standards that must be reached for the initiative to be considered successful have not yet been defined, but some basic quantitative and qualitative data are provided.

(6) The evidence that will be used to indicate how the initiative has performed and demonstrate its results (outputs and outcomes) is that the IICA has been codified in the GIEC.

ShouldEP, MP, SP, LP and OP 'systems' be required tomanage the implantation results systematically and support internal and external research attempts to obtain extensive knowledge about various subject fields? There is no further information in Fathi (2017, p. 222), but the answer is likely to be that this is a decision to be made on an ad hoc basis.

Systems and the improvement and amending of activities

The final issue is whether it would be required for EP, MP, SP, LP and OP 'systems' to have 'adequate and sufficient practical, theoretical and analytical information for improving and amending the activities' (Fathi, 2017, p. 222). The answer must be that it would be desirable that it would be also desirable for codification.

Some final remarks

This seminal work has tried to explore to what extent standardisation in general (with some references to Catalan restandardisation) can be evaluated as TP and LPP for ethical, academic and epistemological reasons, and academic and contextual opportunities, and being based on some assumptions about LPPE, TPE, LSE in general and the Catalan restandardisation evaluation. The general question addressed was to what extent standardisation can be evaluated according to some models for TPE (Fathi, 2017) and LPPE (Gazzola 2014). After presenting Haugen's (1983) model of standardisation with complementary concepts of Cooper (1989) and Cerruti, Crocco, and Marzo (2017), this model was analysed from the perspectives of Fathi (2017) and Gazzola's 2014, with references to what has been carried out in the official Catalan restandardisation. As for this issue, this work assumes that there are at least tenethical, academic and epistemological reasons, as well as academic and contextual opportunities, for exploring the possibility of evaluating the restandardisation of Catalan, as reflected in the new official grammar and orthography introduced by the Institute of Catalan Studies (IEC, 2016; IEC, 2017). The hypothesis to be confirmed in this work, that Catalan restandardisation can be evaluated in the same way as TP, since standardisation is epistemologically and professionally at an intermediate level between TP (Fathi, 2017 , p. 22 ,

27) and LPP, has been confirmed. With respect to methodology, a summary has been made of what has been written in the official Catalan standardisation documents (Costa, accepted). The final remarks of this work, translated, are: that the analysis of the texts of the IEC on the official Catalan restandardisation has shown that neither the definition of the problem nor the one of the target population is sufficiently precise to be the origin of a systematic set of objectives nor the establishment of a target population. On this last aspect, the forecast for the fall of 2018 of two simplified editions of the GIEC and the continuous dialogue with stakeholders in restandardisation (linguistic advisers of the media, teachers, writers and translators) make clear that the IEC is aware of certain specificities among the target beneficiaries.

Finally, the extent to which Fathi's (2017) proposal for a TPE would be applicable to evaluation was examined and resulted in a largely, affirmative answer, although with some adaptations to be made and aspects to be developed. 
Regarding the original contributions of this work, it must first be said that analysing Haugen's model from Fathi's and Gazzola's evaluation models is a new approach and, secondly, as the positive verification of the hypothesis shows in the section 'Verification of the hypothesis', especially the questions raised from Fathi's (2017) conclusions (in the section 'To what extent would Fathi's (2017) proposal for a TPE be applicable to standardisation evaluation?'), the evaluation of the codification implantation can be undertaken on an academic, theoretical and epistemological basis. One specific result is the confirmation of the parallelism between TP and codification planning procedures, since almost everything that Fathi (2017) proposes for TP evaluation is applicable to codification.

This can be carried out keeping in mind that Fathi (2017) herself makes the relevance criterion pertinent for evaluating 'language policies'. However, it must be remembered that the target sets for codification plans are, in principle, all community members, whereas the target sets for terminological plans are field specialists. This difference makes evaluating codification plans more difficult than evaluating terminological plans.

\section{Notes}

1. As we do not have enough room, we ruled out Garvin's (1992) and Lamuela's (1994) concepts.

2. Other terms are not taken into account in this work: Lüdi (2011) talks about restandardisation when he refers to the emergence of new norm-setting centres in the context of pluricentricity (see also Amorós 2014); Kaplan \& Baldauf (1997) use the term "unplanned" language change; Spolsky (2004, p. 222) states that "the real language policy of a community is more likely to be found in its practices than in management".

3. See, for the Catalan context, Boix and Vila (1998, pp. 288-295) and Vila \& Nogué (2007, p. 35).

4. Their capacity of being agents and actors in bottom-up policies should not be ruled out.

5. Kaplan and Baldauf (1997, p. 95) state that "it is far more difficult to conduct cost-benefit analysis as part of human resource development [...], but it is nevertheless desirable to do so." And Thornburn (1971, pp. 253-262).

6. This issue is extensively analysed in Costa (accepted), so only the results are presented here, merely as a way of providing a real example of the issues discussed in this work.

7. These are some of the most important evaluation criteria in language policy and planning evaluation (Gazzola 2014, pp. 89-90).

8. It must be said that the IEC shows an awareness of the diversity of its target beneficiaries by

(a) working on two simplified versions of its grammar to be published by autumn 2018 (online) and winter 2019, and (b) holding periodical workshops ("open academies") with three "stakeholder" groups: media linguistic advisers, teachers and writers.

9. There is no room to analyse neither the relationship between "grammatication" and "lexication" and "stylistic development" nor the relationship between "lexication" and "terminological modernisation".

10. We are already working on developing the issues put forward in this section.

11. As these last four "elements" are very specific and there is not enough room to discuss them, they are not going to be dealt with.

12. Fathi (2017, pp. 7-8) refers to "terminology planning systems". Are demography, culture, ethnolinguistics, geolinguistics and social psychology "systems" which have factors in common with the TP system? If TP is an "elaboration/cultivation" activity that is included in standardisation/LCP: is it then a sub-system of LCP or is LCP a super-system in relation to TP? In Haugen's model (which is cited by Fathi) selection, codification and implementation would be standardisation sub-systems, surely? Is it a problem if TP is, at the same time, a super-/supra-, a subor just a system?

13. Since these are language changes, William Labov's perspective should be pertinent, as well as Ivàlua's theory of change (Ivàlua Guia pràctica 1).

14. See Garvin (1992) and Lamuela (1994).

15. My comments and adaptations. Compare these definitions to those of Gazzola (2014).

\section{References}

Amorós, C. (2008). La evaluación de la planificación lingüística. In Norma y estandarización (pp. 89-93). Luso-Española de Ediciones: Salamanca. 
Amorós, C. (2014). Las lenguas en la sociedad. Madrid: Síntesis.

Bastardas-Boada, A. (1995). Language management and language behavior change: Policies and social persistence. International Journal of Catalan Culture, IX(2), 15-38.

Boix, E., \& Vila, X. (1998). Sociolingüística de la llengua catalana. Barcelona: Ariel. Retrieved from

http://www.academia.edu/8887181/Socioling\%C3\%BC\%C3\%ADstica_de_la_llengua_catalana Cerruti, M., Crocco,

C., \& Marzo, S. (2017). On the development of a new standard norm in Italian.

In M. Cerrutti, C. Crocco, \& S. Marzo (Eds.), Towards a new standard. Theoretical and empirical studies on the restandardisation of Italian (pp. 3-28). Boston: Walter de Gruyter.

Cooper, R. L. (1989). Language planning and social change. Cambridge: Cambridge University Press.

Corbeil, J.-C. (2007). Le rôle de la terminologie en aménagement linguistique: genèse et description de l'approche québécoise. Langages, 168, 92-105.

Costa, J. (2009). La norma sintàctica del català segons Pompeu Fabra. Munchen: Peniope. Retrieved from http://repositori.upf.edu/handle/10230/26054

Costa, J. (2013). La recerca sobre normativa: proposta general. Treballs de Sociolingüistica Catalana, 23, 269-286. Retrieved from http://publicacions.iec.cat/repository/pdf/00000205/00000078.pdf. [Translation into English in progress].

Costa, J. (2016a). La planificació de corpus: estat de la question. Treballs de Sociolingüística Catalana, 26, $123-$ 137.

Costa, J. (2016b). Sobre el "marc de condicions sociolingüístiques favorables" per a laimplantació de la normativa lingüística catalana. Caplletra. Revista Internacional de Filologia, 61 (tardor), 123-152. Retrieved from http://roderic.uv.es/handle/10550/56648

Costa-Carreras, J. (2018). La introducció de l'infinitiu complement o adjunt a la Gramàtica de la llengua catalana: una proposta d'avaluació. Revista de Llengua i Dret, Journal of Language and Law, núm. 69 (june), 154-175. Retrieved from http://revistes.eapc.gencat.cat/index.php/rld

Costa, J. (2019). És la "variació lingüística social" una categoria operativa per a la planificació lingüística de corpus? Caplletra, 67.

Costa-Carreras, J. (in press). El "marc de condicions sociolinguiístiques favorables": aplicació a la "Gramàtica de la llengua catalana” (2016). In Actes del congrés Évaluer les politiques linguistiques Quels objectifs, critères, indicateurs? Xèmes Journées des Droits Linguistiques - JDL 2016 Colloque international (Décembre 2016).

Costa, J. (accepted). L'avaluació de la reestandardització del català: la definició del problema.

Fathi, B. (2017). Terminology Planning Evaluation: The Case of Persian Language. [PhD. thesis UPF / 2017. Directora de la tesi: Dra. M. Teresa Cabré. Institut de Lingüística Aplicada. Departament de Traducció i Ciències del Llenguatge. Universitat Pompeu Fabra. 297 p.] PDF copy.

Garvin, P. (1992). La langue standard: Concepts et processus. In Ii Congrés Internacional de la Llengua Catalana. Àrea 3: Lingüística social (pp.503-514). Palma: Universitat de les Illes Balears.

Gazzola, M. (2014). The evaluation of language regimes: Theory and application to multilingual patent organisations. Amsterdam: John Benjamins.

Haarman, H. (1990). Language planning in the light of a general theory of language: A methodological framework. International Journal of the Sociology of Language (IJSL), 86, 103-126.

Haugen, E., \& Dill, A. S. (1972). Schizzoglossia and the linguistic norm. In The ecology of language: essays by Einar Haugen (pp. 148-158). Stanford: Stanford University Press.

Haugen, E. (1983). The implementation of corpus planning: Theory and practice. In J. Cobarrubias, \& J. A. Fishman (Eds.), Progress in language planning: International perspectives (pp. 269-289). Amsterdam: Mouton.

IEC: Estatuts de l'Institut d'Estudis Catalans. (2015). Available at http://transparencia.iec.cat/wpcontent/uploads/2015/07/Estatuts_iec.pdf. Consulted on April 11th 2018.

IEC: Institut d'Estudis Catalans. (2016). Introducció. In Institut d'Estudis Catalans. Gramàtica de la llengua catalana. Barcelona: Author (pp. XIX-XXXVIII).

IEC: Institut d'Estudis Catalans. (2017). Introducció. In Institut d'Estudis Catalans. Ortografia catalana. Barcelona: Author (pp. 13-20). Retrieved from https://www.iec.cat/llengua/documents/ ortografia_catalana_versio_digital.pdf

Ivàlua Guia pràctica 8. La metodologia qualitativa en l'avaluació de polítiques públiques. Retrieved from http://www.ivalua.cat/documents/1/11_04_2011_10_41_12_Guia8_MetodologiaQualitativa.pdf

Ivàlua Guia pràctica 1. Com iniciar una avaluació: oportunitat, viabilitat i preguntes d'avaluació. Retrieved from http://www.ivalua.cat/documents/1/16_02_2010_10_18_20_Guia1_Introduccio_

Abril2009versiorevisada_final.pdf

Joseph, J. E. (1987). Eloquence and power: The rise of language standards and standard languages. Londres (London): Frances Pinter.

Kaplan, R. B., \& Baldauf, R. B. Jr. (1997). Language planning. From practice to theory. Clevedon: Multilingual Matters. 
Labèrnia, A. (2015). La incidència de certs factors sociolingüístics en la implantació de setze variants sintàctiques en català. PhD. thesis. Available at http://www.tdx.cat/handle/10803/315284

Lamuela, X. (1995, September). Criteris de codificació i de compleció lingüístiques». Els Marges, 53, 15-30.

Lamuela, X. (1994). Estandardització i establiment de llengües. Barcelona: Edicions 62.

Lüdi, G. (2011). Can French be called a pluricentric language? In A. Soares Da Silva, A. Torres, \& M. Gonçalves (Eds.), Línguas Pluricèntricas.Variaçao Linguística e Dimensôes Sociocognitivas/ Pluricentric Languages. Linguistic Variation and Sociocognitive Dimensions (pp. 87-107). Braga: Publicaçoes da Faculdade de Filosofia/Universidade Católica Portuguesa.

Martí, J. (2006). Introducció. In Institut d’Estudis Catalans. Diccionari de la llengua catalana. Barcelona: Author. Retrieved from http://dlc.iec.cat/]

PEO1: Institut d'Estudis Catalans. (1999). Introducció. In Proposta per a un estàndard oral 1. Fonètica. Barcelona: Author. Retrieved from http://publicacions.iec.cat/repository/pdf/ 00000039/00000072.pdf

PEO2: Institut d'Estudis Catalans. (1999). Introducció. In Proposta per a un estàndard oral 2. Morfologia. Barcelona: Author. Retrieved from http://publicacions.iec.cat/repository/pdf/ 00000062/00000073.pdf

Ricento, T. (2016). Language policy and political economy. English in global context. Oxford: Oxford University Press.

Rubin, J. (1971). Evaluation and language planning. In J. Rubin \& B. H. Jernudd (Eds.), Can language be planned? Sociolinguistic theory and practice for developing nations (pp. 217-252). Honolulu: The University Press of Hawaii.

Shohamy, E. (2006). Language policy and language planning. Hidden Agendas and New Approaches. London: Routledge.

Spolsky, B. (2004). Language policy. Key topics in sociolinguistics. Cambridge: Cambridge University Press.

Thornburn, T. (1971). Cost-Benefit analysis in language planning. In J. Rubin, \& B. H. Jernudd (Eds.), Can language Be Planned? Sociolinguistic theory and practice for developing nations (pp. 253-262). Honolulu: The University Press of Hawaii.

Vila, X., \& Nogué, M. (2007). L'anàlisi de la implantació terminológica en comunitats d'usuaris reduïdes: algunselements metodològics des de la sociolingüística. In X. Vila (dir.), Estudis d'implantació terminològica: Una aproximació en l'àmbit dels esports. Barcelona: TERMCAT. 